\title{
Proton pump inhibitors and hypomagnesemia monitoring
}

This article was published in the following Dove Press journal:

International Journal of General Medicine

19 August 2013

Number of times this article has been viewed

\section{Thomas I Lemon \\ Institute of Medical Education, Cardiff University School of Medicine, Cardiff, UK}

Correspondence: Thomas I Lemon Institute of Medical Education, Cardiff University School of Medicine, Cochrane Medical Education Centre, Health Park, Cardiff CFI 4 4YU, UK Email lemonti@cf.ac.uk

\section{Dear editor}

I thank El-Charabaty et $\mathrm{al}^{1}$ for their interesting paper which concludes that patients in receipt of proton pump inhibitors (PPIs) need to be followed closely for magnesium deficiency, particularly in the face of acute cardiovascular events, as this may worsen arrhythmias and hence increase the likelihood of complications. I would of course reference Faulheber et al's recent paper that highlights the fact that hypomagnesemia in PPI use is uncommon ${ }^{2}$ - but of course, uncommon does not mean never, and as such the former's conclusion is sound advice to all juniors and seniors alike.

El-Charabaty et al's transparency regarding limitations was exemplary, particularly their acknowledgment of the observational status of the study. ${ }^{1}$ It would be interesting to see the results in a study drawn from an outpatient setting, as close monitoring in that domain could significantly add to the workload of primary care physicians. I also feel that diuretic use, which has been associated with PPI hypomagnesemia, could be analyzed in these settings.

To conclude, this is a relevant study, which highlights an important clinical monitoring situation.

\section{Disclosure}

The author reports no conflicts of interest in this work.

\section{References}

1. El-Charabaty E, Saifan C, Abdallah M, et al. Effects of proton pump inhibitors and electrolyte disturbances on arrhythmias. Int J Gen Med. 2013;6:515-518.

2. Faulhaber GA, Ascoli BM, Lubini A, et al. Serum magnesium and proton-pump inhibitors use: a crosssectional study. Rev Assoc Med Bras. 2013;59(3):276-279.

\section{Publish your work in this journal}

The International Journal of General Medicine is an international, peer-reviewed open-access journal that focuses on general and internal medicine, pathogenesis, epidemiology, diagnosis, monitoring and treatment protocols. The journal is characterized by the rapid reporting of reviews, original research and clinical studies across all disease areas.
A key focus is the elucidation of disease processes and management protocols resulting in improved outcomes for the patient. The manuscript management system is completely online and includes a very quick and fair peer-review system. Visit http://www.dovepress.com/ testimonials.php to read real quotes from published authors. 